\title{
GLI Family Gene
}

National Cancer Institute

\section{Source}

National Cancer Institute. GLI Family Gene. NCI Thesaurus. Code C18529.

GLI Family Genes encode DNA-binding GLI Family Proteins containing zinc fing er repeats and involved in pattern formation. 